\title{
Effect of coded Unani formulation UNIM-401 and Soranil with NB-UV-B therapy in a case of chronic Palmo-plantar plaque psoriasis- A Case Study
}

\author{
Misbahuddin Azhar ${ }^{*}$, Zamir Ahmad ${ }^{2}$ \\ ${ }^{1}$ Research Officer Scientist-III, Regional Research Institute of Unani Medicine, Aligarh \\ ${ }^{2}$ Professor, Dept. of Amraz-e-Jild wa Taziniyat, Faculty of Unani Medicine, AMU Aligarh
}

\begin{abstract}
:
$D a^{\prime}$ al-Sadaf (Plaque psoriasis) is the most common form of the psoriasis in which raised, red patches covered with a silvery white buildup of dead skin cells. These patches or plaques most often show up on the scalp, knees, elbows and lower back. Sometimes it is itchy and painful and, may cracked and bleed. Unani oral and topical medicines along with Narrow Band Ultra-Violet (NB-UV-B) therapy is used here for treatment. Unani coded formulation UNIM-401 containing Barg Shahtra (Fumaria parviflora Linn.), Chiraita Talkh (Swertia chirata Buch.), Babchi (Psoralea corylifolia Linn.) and Haleela Siyah (Terminalia chebula Retz.) in the ratio of 5:5:5:2, in a dose of 2 capsules (500 mg each) orally with lukewarm water twice a day in empty stomach for a period of three months are given and Soranil ointment mixed with clarified butter in 1:1 ratio was applied on the affected part and exposed to the NB-UVB light for 10 minutes. Plaques of psoriasis getting shade off after one month of treatment and almost disappeared from the site of lesion after three months. The skin of patient almost become normal. It may be concluded that Unani drugs (oral \& topical) along with NB-UVB therapy is beneficial for controlling and treating plaque psoriasis.
\end{abstract}

Keywords: Da' Al-Sadaf, Palmo-plantar plaque psoriasis, NB-UVB Therapy, Soranil, Unani Medicine, UNIM-401.

Received: 01.04.2021 Revised: 07.05.2021 Accepted: 07.06.2021 Published: 28.06.2021

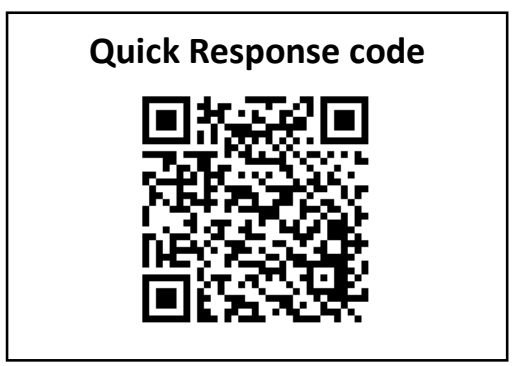

*CORRESPONDING AUTHOR:

\section{Dr. Misbahuddin Azhar}

Research Officer Scientist-III,

Regional Research Institute of Unani Medicine, Aligarh

E-mail : ccrum619@gmail.com 


\section{Introduction:}

Hippocrates (460-377 BC) was the first Greek Physician who described the psoriasis. The psora was derived from the Greek word meaning "to itch". Hippocrates used the terms psora and lepra for conditions that can be recognized as psoriasis. ${ }^{[1]}$ The various Unani scholars have described, Taqashshur-e-Jild/ $D a^{\prime}$ Al-Sadaf (psoriasis) in their treatises such as Raban Tabari (783-858 AD) in Firdaus ul Hikmat, Zakariya Raazi (865-925 AD) in Al Hawi fit Tib, Ibn Sina (980-1037 AD) in AlQanoon fit Tib, Ibn Hubul Baghdadi (11221213 AD) in Kitab Al Mukhtarat. Some other scholars e.g. Najeebuddin Samarqandi (11221213), Akbar Arzani (1722d.) and Azam Khan (1813-1902) also mentioned its causative factors, sign \& systems and Unani treatment with single and compound drugs in details in their treatises. According to Unani philosophy Da' Al-Sadaf/Taqashshur-e-Jild is due to the predominance of Khilt-i-Sawda (black bile)/ burnt black bile which accumulates beneath the skin and cause irritation which leads to intense itching, roughness, scaling and cracking of the skin. When these scales become chronic then they are difficult to treat. The clinical picture of this disease mentioned in Unani classical literature is very resemble to the clinical picture of today's psoriasis. ${ }^{[2-10]}$ In the late 1700s, the English dermatologist Robert Willan recognized psoriasis as its own condition. Psoriasis is a common inflammatory disease of the skin, nails and joints has various systemic associations. Its causes remain unknown but sometimes immune mediated; however, it has been linked to complex interactions between predisposing genes and the environment. ${ }^{[1-16]}$ In classical literature many single and compound drugs are mentioned for the treatment of Taqashshur-eJild/ Da' Al-Sadaf. These Unani drugs successfully treat a host of chronic dermatoses including psoriasis and eczema. ${ }^{[2-9]}$

The incidence of psoriasis among total skin patients ranged between 0.44 and $2.2 \% .^{[17-18]}$
In a clinical observation a combination of Unani formulations (oral and local) showed a good result in a case of psoriasis. ${ }^{[19]}$ The aim of the study was to evaluate the efficacy of a coded Unani formulation UNIM-401 and Unani market sample of topical preparation Soranil with Narrow Band Ultraviolet B (NBUV-B) therapy in a case of Palmo-plantar plaque psoriasis.

\section{Case presentation:}

A 75 years old female patient visited the OPD and presented with large scales on palm and sole with off and on itching. She was diagnosed with palmo-plantar psoriasis in 2004. The plaques were non inflammatory, thick, red and were fairly widespread across the both her palm and sole as shown in picture. There was no history of diabetes, hypertension, or any other systemic ailments and no history of any medication except for psoriasis. There was history of pan, tobacco and beetle chewing from last 30 years. Since 2004 she was under treatment with various dermatologist of different systems of medicines i.e. Allopathic, Ayurvedic Homeopathic and Unani medicine. With every treatment she had some relief in itching and scale formation temporarily but not having complete relief in symptoms even after taking the treatment for three months. There was relapse in symptoms. Before starting the treatment, patient was investigated for her blood sugar fasting, heamogram, liver function, kidney function and repeated after one month and at the end of the treatment. Photograph of patient's both hand and foot were taken before the treatment, after 60 days and after 90 days of treatment.

Patient was given Coded Unani formulation UNIM-401 (2 capsules of $500 \mathrm{mg}$ each) orally with water twice a day empty stomach for 90 days and market sample topical Unani medicine Soranil mixed with clarified butter in 1:1 ratio was applied on the affected part followed by exposure to NB UV-B therapy for 
10 minutes continuously for 15 days followed by with 10 days gap. During the gap Soranil was continued to apply on the affected part twice in a day exposed to the sunlight in the morning.

Coded Unani formulation UNIM-401 containing Barg Shahtra (Fumaria parviflora Linn.), Chiraita Talkh (Swertia chirata Buch.), Babchi (Psoralea corylifolia Linn.) and Haleela Siyah (Terminalia chebula Retz.) in the ratio of 5:5:5:2 formulated as dried aqueous extract in capsule form of $500 \mathrm{mg}$ each was prepared by Central Council for Research in Unani Medicine (CCRUM) in their pharmacy at Central Research Institute of Unani Medicine (CRIUM), Hyderabad. ${ }^{[20]}$

Market sample Unani topical medicine Soranil ointment. Each $50 \mathrm{gm}$ contains the following ingredients in the ratio as mentioned in Table 1.

Table 1: Ingredients of Soranil ointment:

\begin{tabular}{|l|l|l|}
\hline Unani name & Scientific/English name & Quantity \\
\hline Ratanjoot & Onosma echioides Linn. & $5 \mathrm{gm}$ \\
\hline Murdarsang & Massicot/Lead oxide/Plumbioxidum & $5 \mathrm{gm}$ \\
\hline Tinkar & Ore-borax / Sodium biborate & $5 \mathrm{gm}$ \\
\hline Kibreet/Gandhak & Sulphur purified & $5 \mathrm{gm}$ \\
\hline Kafoor & Cinnamomum camphora (Linn.) J. Presl & $5 \mathrm{gm}$ \\
\hline RoghanNarjeel & Oil of Cocos nucifera Linn. & $5 \mathrm{gm}$ \\
\hline Petroleum jelly & Petroleum Jelly & $10 \mathrm{gm}$ \\
\hline Mom Zard/Bee wax & Cera alba & $10 \mathrm{gm}$ \\
\hline
\end{tabular}

\section{Study center:}

The study was conducted jointly in out-patient department of Regional Research Institute of Unani Medicine (RRIUM), Aligarh and Department of Amraz-e-Jild wa Taziniyat, Faculty of Unani Medicine, AMU Aligarh.

\section{Outcome and follow-up:}

It was observed that after taking the above treatment for the period of three months, patient start getting relief after 30 days of treatment. All the laboratory test results were in normal limit at the base line, after 30 days and 90 days treatment with the coded Unani formulation UNIM-401 and Unani topical medicine Soranil ointment with clarified butter in 1:1 ratio followed by NB-UVB therapy as described earlier. There was difference in the values of many markers but they were not statistically significant. Here we are presenting the photograph of patient's affected parts (both hand and foot) taken a baseline Fig-1A,1B,1C, after 60 days Fig-2A,2B,2C and at the end of the treatment Fig-3A,3B,3C. The photographs of the patient clearly showed the positive effect of coded Unani formulation UNIM-401 and Unani topical medicine Soranil ointment with NB-UVB therapy in this case. The scales of hand and feet of patient of plaque psoriasis shade off and skin become all most normal after the treatment of 90 days Fig-3A, 3B,3C. Some scales are still present on the foot of the patient. These photographs are selfexplanatory for the beneficial effect of coded Unani formulation UNIM-401, Soranil along with NB-UVB therapy in this case of palmoplanter psoriasis. The quality of life of patient improves in comparison to baseline to after 90 days of treatment. These effects may be due to the action of ingredient mentioned in Unani literature.

The ingredients of Coded Unani formulation UNIM-401 collectively having Musaffi-i-Dam (blood purifier), Muqawwi-i-Mi'da (stomachic), Mushtahi (appetizer), Mulayyan (laxative), Mudir-i-Bawl (diuretic), Dafi' Hummiyat Balghamia (antipyretic), Muhallil (anti-inflammatory), Muqawwi-i-Jigar (liver 
tonic), Dafi' Ta'ffun (antiseptic), Kasir-iRiyah (carminative), jali (detergent), Dafi' Bars wa Behaq (anti vitiligo and pityriasis), Mushil Akhlat-i-Salasa (purgative for three humours) actions. ${ }^{[21]}$ The ingredients of market drug soranil collective having Qabid (astringent), Mujaffif (demulcent), Jali (detergent), Muqqat-i-Mawad (diversion of morbid material), Mudammil-i-Qurooh (wound healer), Akkal (corrosive), Dafi'
Ta'ffun (antiseptic), Muhallil-i-Awram (antiinflammatory) actions ${ }^{[21]}$. Coded Unani formulation UNIM-401 along with Soranil ointment showed positive effect in reducing the plaques in a case of palmo-planter psoriasis as shown in figure. In an earlier study UNIM-401 also showed good effect in noninferiority randomized controlled clinical trial comparing with psoralen plus ultraviolet A sol in chronic plaque. ${ }^{[20]}$

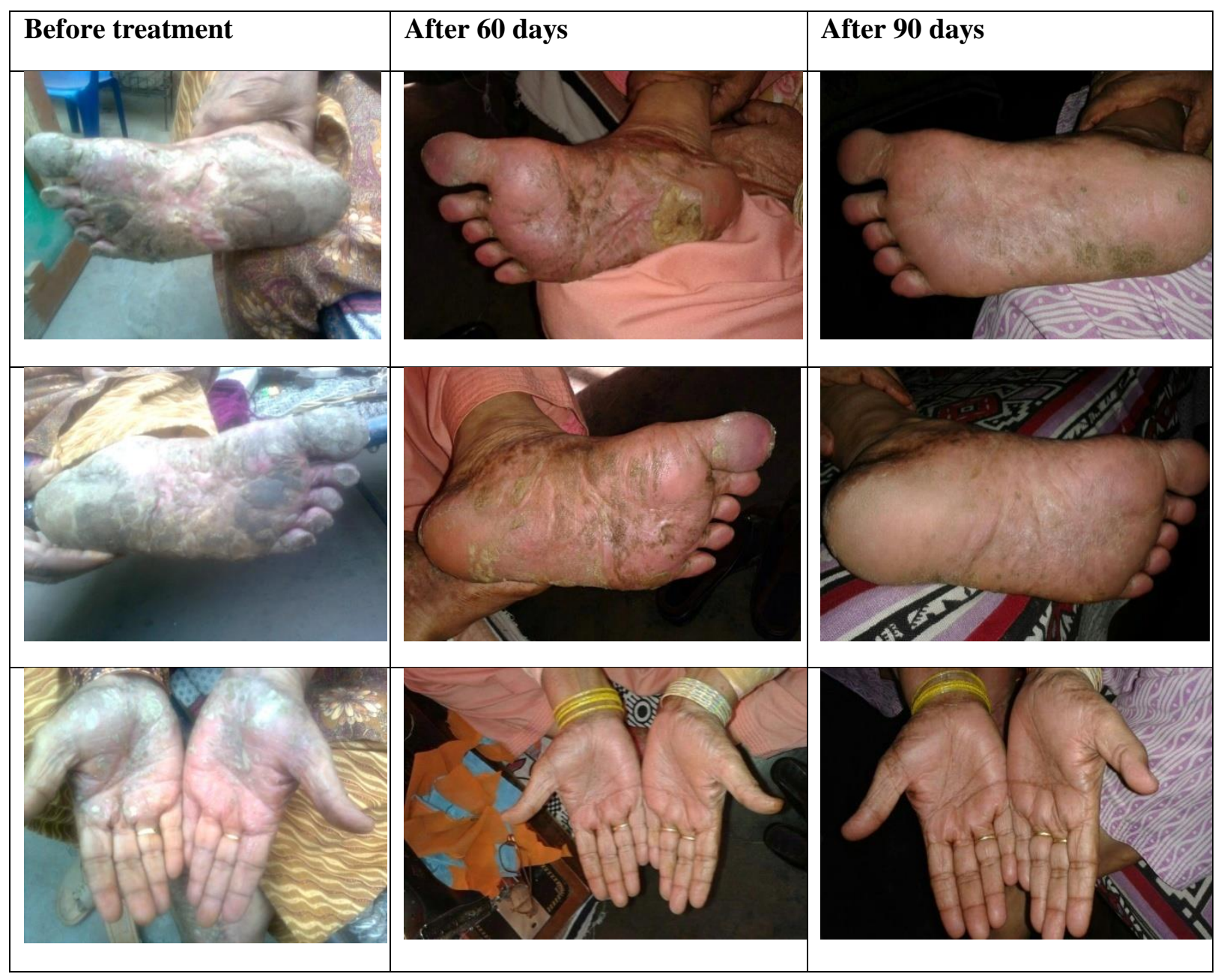




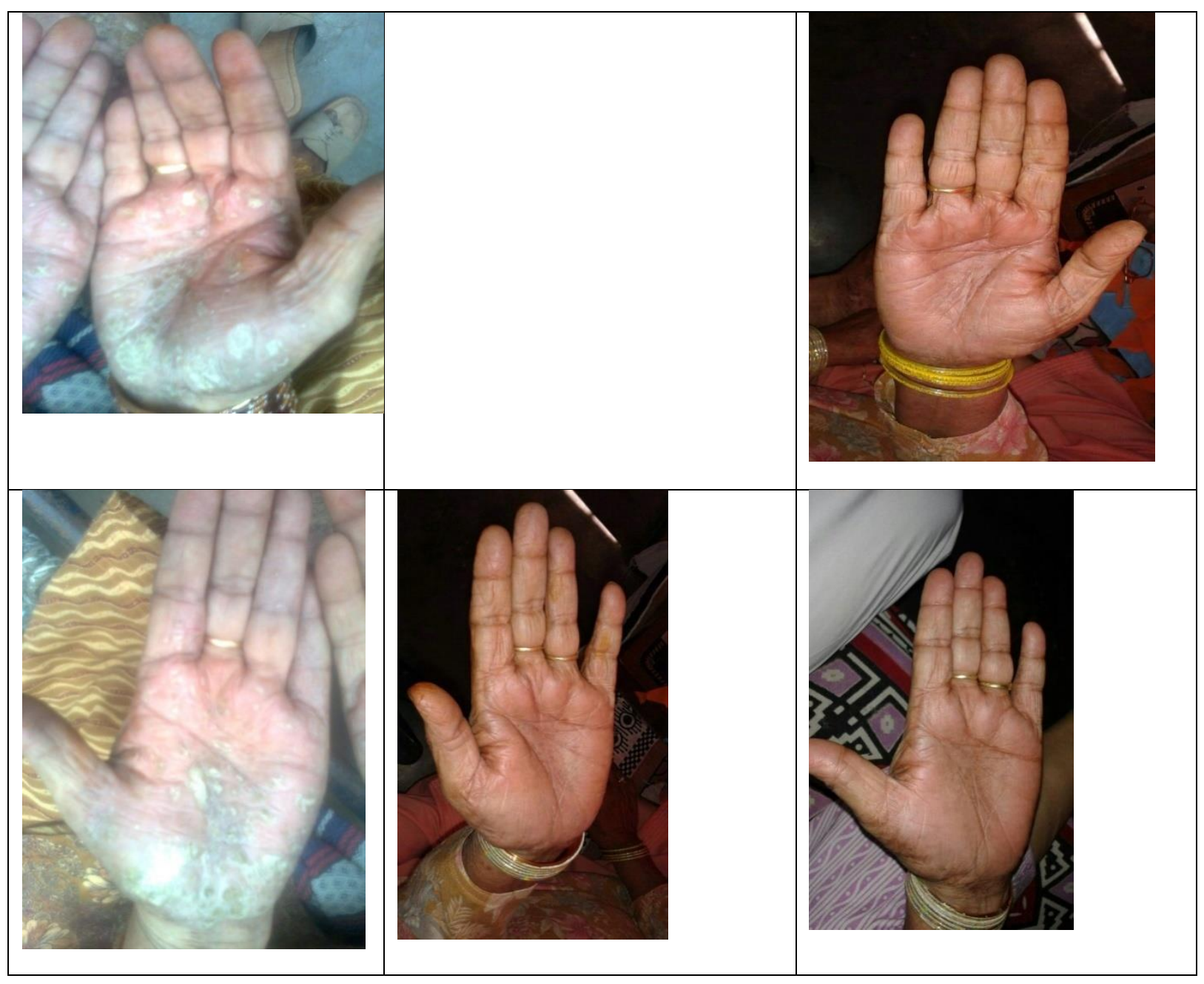

Fig: 1. Effect of UNIM-401 and Soranil ointment on foot and hands in a case of chronic palmoplantar plaque psoriasis

\section{Discussion:}

Unani materia medica is very rich that covering three sources of medicine (animal, herbal and mineral products) and offers safe and effective treatment for many disease e.g. $\mathrm{CKD}^{[22-24]}$, Hepatosplenomegaly ${ }^{[25]}$, dyslipidemia $^{[26]}$, Seborrheic Dermatitis ${ }^{[27]}$ etc. These results suggest that this combination therapy UNIM-401 and Soranil ointment along with NB-UVB therapy resulted in an early and a good improvement in the quality of life of patient suffering from palmo-plantar plaque psoriasis. It also shows that NB-UVB in combination with UNIM-401 is more efficacious in the treatment of palmo-plantar plaque psoriasis. It may be concluded that the above combination of coded Unani formulation UNIM-401 with NB-UVB therapy may be used in a large number of cases of plaque psoriasis for establishing the result of this disease condition due to its antiseptic, anti-inflammatory, morbid matter divergent, wound healer, blood purifier, detergent, corrosive properties of ingredients.

\section{Conclusion:}

On the basis of this single case study it is concluded that coded Unani formulation UNIM-401 and Soranil with NB-UV-B therapy is effective in chronic Palmo-plantar plaque psoriasis 


\section{Limitation of the study:}

In this study results are also promising and giving a line for further exploration of these Unani formulations in large sample size for the benefit of mankind. This is suggested that scientific community must take up this job and well-planned study may be conducted to establish its rate of efficacy in large sample size.

\section{Consent of patient:}

The consent of patient was dully taken at the time for registration as per ethics for treatment and publication without disclosing the identity of patient.

\section{Acknowledgement:}

Authors are thankful to technical staff of laboratory of Regional Research Institute of Unani Medicine, Aligarh and Department of Amraz-e-Jild wa Taziniyat, Faculty of Unani Medicine, AMU Aligarh for pathological investigations and NB-UVB therapy. We are also thankful to Director, Central Research Institute of Unani Medicine, Hyderabad for proving UNIM-401.

\section{References:}

1. Glickman FS, Lepra, psora, Psoriasis. J Am Acad Dermatol. 1986; 14(5 Pt 1) pp. 863-866.

2. Razi Z. Al Hawi Fil Tib. (Arabic). Vol. XXXIII. Dairat-ul-Maarif. Hyderabad, India), 1994; pp. 23,72.

3. Ibn Hubal. Kitabul Mukhtarat Fit Tib. (Urdu translation), Central Council for Research in Unani Medicine publication; New Delhi India, 2007; pp. 120-121.

4. Ibn Sina. Al-Qanoon Fil Tib. (Urdu Translation). Vol. IV, Book Printer Lahore Pakistan, 1992; pp. 226-228.

5. Jurjani I. Zakhira-e-Khawarizam Shahi. Vol. VIII, Matba Munshi Nawal Kishore Lucknow, 1882; pp 6-8.
6. Khan A. Akseer Azam. Vol IV, Matba Nawal Kishore Lucknow, 1885; pp. 511512.

7. Majoosi AA. Kamilus Sana, (Urdu translation), Vol-II. Matba Nami Munshi Nawal Kishore Lucknow, YNM; pp. 252.

8. Tabri R. Moalijat-e-Baqratiya. (Urdu Translation), Vol-II, (Central Council for Research in Unani Medicine Publication New Delhi, India, 1997; pp 185.

9. Ibn Zohar. Kitab-ul-Taiseer Fil Mudawat wa Tadabeer. (Urdu translation), Central Council for Research in Unani Medicine Publication New Delhi, India, 1986; pp. 205.

10. Azhar MU, Quddusi N, Parveen S, Tajuddin, Siddiqui KM, Siddiqui MK. Daa-us-Sadaf (Psoriasis) and role of herbal drugs. Hamdard Medicus. 2010; 53(1): 5157.

11. Hunziker T, Schmidli J. Psoriasis, an auto immune disease?, TherUmsch., 1993; 50 (2):110-113.

12. Griffiths CE, Voorhees JJ. Psoriasis, T cells and auto immunity. J R Soc Med, 1996; 89 (6):315-319.

13. Braunwald E, Fauci AS, Kasper DL, Hauser SL, Longo DL, Jamesan JL. Harrison's Principal of Internal Medicine, Mac Graw Hill Book Co Singapore, 1998; pp 300-301.

14. Goldman L, Bennet JC. Celil's Textbook of Medicine. 21st edn. Harcourt Asia Pvt. Ltd., A Harcourt Publisher, International Company, Orchard Road; Singapore, 2000; pp 9-11.

15. Edward CRW, Bouchier IAD, Haslett C, Chilvers ER. Davidson's Principles and Practices of Medicine. XXVIII edn. Churchill living stone, London, 2006; pp 1287-1292.

16. Gupta SK, Singh KK, Lalit M. Comparative therapeutic evaluation of different topical and narrow band ultraviolet $b$ therapy combined with systemic methotrexate in the treatment of 
palmoplantar psoriasis. Indian J Dermatol, 2011; 56 (2) :165-170.

17. Kaur I, Handa S, Kumar B. Natural history of psoriasis: a study from the Indian subcontinent. J Dermatol., 1997; 24 (4):230-234.

18. Venkatesan A, Aravamudhan R, Perumal SK, Kannan R, Thirunavukkarasu V, Shukla S. Palmoplantar Psoriasis- Ahead in the Race-A Prospective Study from a Tertiary Health Care Centre in South India. Journal of Clinical and Diagnostic Research, 2015; 9, pp WC01-WC03.

19. Qureshi MA, Bano H. Clinical observation of Unani medicine in the treatment of psoriasis: a case study, Indian Journal of Traditional Knowledge, 2019; 18(1) 191192.

20. Khanna N, Nazli T, Siddiqui KM, Kalaivani M, Rahman R. A non-inferiority randomized controlled clinical trial comparing Unani formulation \& psoralen plus ultraviolet A sol in chronic plaque psoriasis. Indian J Med Res, 2018; 147 (1): 66-72.

21. Rafiquddin M. Kunzul Advia-e-Mufradat, University publication unit, Sarfaraz house Aligarh, India, 1985; pp. 131-132, 280281, 360-361, 452-453, 526-528, 597-599, 630-631, 681-682.

22. Azhar MU. Effect of herbal Unani formulation on Nephrotic syndrome: A case study, Indian Journal of Traditional Knowledge, 2018; 17(4), 807-810.

23. Alam MMA, Javed K, Jafri MA. Effect of Rheum emodi (Revand Hindi) on renal functions in rats, Journal of
Ethnopharmacology, 2005; 96 (1-2) 121125.

24. Javaid R, Aslam M, Javaid R, Nizami Q, Javed K, Azhar MU, Extract of Ferula foetida Regel reverses gentamicin induced nephrotoxicity in rats, EXCLI Journal 2012;11:760-766

25. Azhar MU; Ansari RI, Ahmad S. Clinical Effect of Barg-e-Jhao (Tamarix articulata Vahl.) in Hepatosplenomegaly-A Case Study, Int. J. AYUSH CaRe, 2019; 3(2) 128-135.

26. Azhar MU, Ayub S, Anjum M, Ahmad S. Effect of Jawarish Bisbasa on dyslipidemia - A case study, International Journal of Scientific Research in Biological Sciences, 2020; 7 (1), 20-23.

27. Azhar MU, Ahmad Z, Mustehasan. Effect of Unani Medicine in Iltehab-e-Jild Huzaazi (Seborrheic Dermatitis) of Head: A case study, International Journal of Scientific Research in Biological Sciences, 2020; 7 (2), 41-43.

Conflict of interest: Author declares that there is no conflict of interest.

Guarantor: Corresponding author is guarantor of this article and its contents.

\section{Source of support: None}

\section{How to cite this article:}

Azhar M, Ahmad Z. Effect of coded Unani formulation Unim-401 and Soranil with NBUV-B therapy in a case of chronic palmoplantar plaque psoriasis- A Case Study. Int. J. AYUSH CaRe. 2021; 5(2):71-77. 